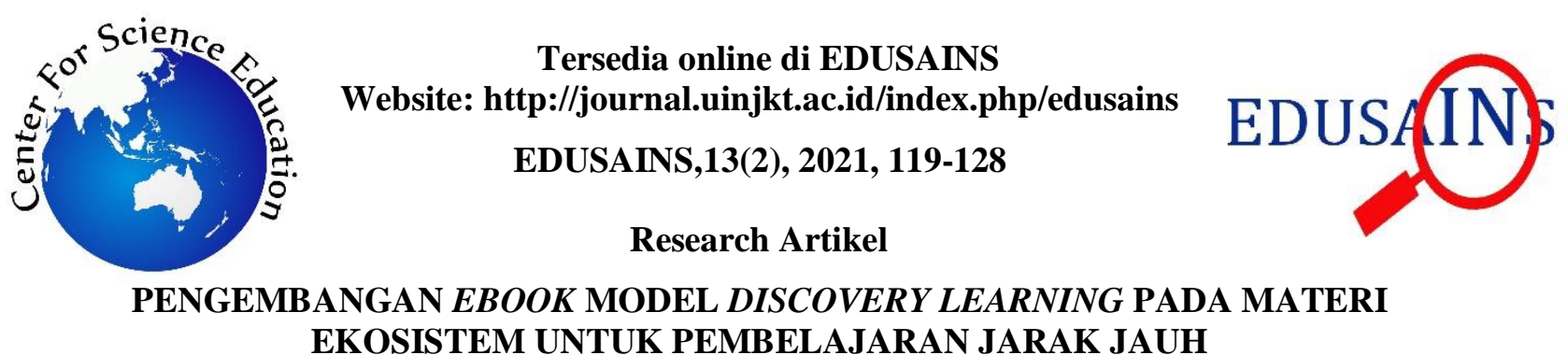

\title{
DISCOVERY LEARNING MODEL EBOOK DEVELOPMENT ON ECOSYSTEM MATERIALS FOR DISTANCE LEARNING
}

\author{
Yunita Kurniasih $^{1 *}$, Diana Vivanti Sigit ${ }^{2}$, Tri Handayani Kurniati ${ }^{2}$ \\ ${ }_{1,2,3}$ Magister Pendidikan Biologi Universitas Negeri Jakarta, Indonesia \\ yunitakurniasih48@gmail.com, 081296034371
}

\begin{abstract}
The covid-19 pandemic requires students to study from home, so appropriate teaching materials such as ebooks are needed. The purpose of this research is to develop an ebook discovery learning model for ecosystem materials to support distance learning. The method used is research and development through six stages, namely data collection, planning, initial product creation, small-scale trials, revisions, and large-scale trials. The results of the research are in the form of an ebook on discovery learning model ecosystem materials that are suitable for students needs. The ebook was validated by media experts, material experts, and linguists then tested on students with small and large scale numbers. Samples were taken using a purposive sampling technique involving 10 students for a small scale and 60 students for a large scale. Data collection techniques using questionnaires and interviews. The results of the validation test by media experts were $84 \%$ (very good), material and language experts were $89,3 \%$ (very good). The results of the student response questionnaire to the use of ebooks are $87 \%$ in the high category. These results show that the ebook discovery learning model ecosystem material developed is very good for use by students during distance learning.
\end{abstract}

Keywords: teaching materials; discovery learning; ebooks; ecosystem; distance learning.

\begin{abstract}
Abstrak
Pandemi covid-19 mengharuskan siswa belajar dari rumah, sehingga dibutuhkan bahan ajar yang sesuai seperti ebook. Tujuan dari penelitian ini adalah mengembangkan ebook model discovery learning materi ekosistem untuk mendukung pembelajaran jarak jauh. Metode yang digunakan yaitu research and development melalui enam tahapan, yaitu pengumpulan data, perencanaan, pembuatan produk awal, uji coba skala kecil, revisi, dan uji coba skala besar. Hasil penelitian berupa ebook materi ekosistem model discovery learning yang sesuai dengan kebutuhan siswa. Ebook divalidasi oleh ahli media, ahli materi, dan ahli bahasa kemudian diujicobakan pada siswa dengan jumlah skala kecil dan skala besar. Sampel diambil menggunakan teknik purposive sampling yang melibatkan 10 orang siswa untuk skala kecil dan 60 siswa untuk skala besar. Teknik pengumpulan data menggunakan kuesioner dan wawancara. Hasil uji validasi oleh ahli media sebesar 84\% (kategori sangat baik), ahli materi dan bahasa sebesar 89,3\% (kategori sangat baik). Hasil angket respon siswa terhadap pemakaian ebook sebesar $87 \%$ dengan kategori tinggi. Hasil ini menunjukkan ebook materi ekosistem model discovery learning yang dikembangkan sangat baik untuk digunakan oleh siswa saat pembelajaran jarak jauh.
\end{abstract}

Kata Kunci: bahan ajar; discovery learning; ebook; ekosistem; pembelajaran jarak jauh.

Permalink/DOI: http://doi.org/10.15408/es.v13i2.21876

*Corresponding author

This is an open access article under CC-BY-SA license (https://creativecommons.org/licenses/by-sa/4.0/) 


\section{PENDAHULUAN}

Bahan ajar merupakan salah satu unsur yang penting untuk siswa dalam mencapai tujuan pembelajaran. Belawati (2003) menyatakan bahan ajar dikelompokkan menjadi empat berdasarkan bentuknya, yaitu bahan cetak seperti handout, buku, modul, lembar kerja siswa; bahan ajar dengar seperti kaset, radio; bahan ajar pandang dengar seperti film; dan bahan ajar interaktif seperti compact disk interactive. Bahan ajar yang umumnya digunakan di Sekolah berupa buku teks pelajaran, modul, LKS, dan buku praktikum karena mudah ditemukan dan didapatkan.

Menurut Asyhari \& Silvia (2016) buku teks memiliki kekurangan yaitu kurang menarik, tidak dapat digunakan dalam tempat gelap, dan membosankan. Ruddamayanti (2013) menambahkan bahwa buku teks mudah rusak, basah, hilang, robek, tulisannya dapat pudar, dan sebagainya. Berbeda dengan buku digital atau ebook yang terhindar dari masalah-masalah tersebut. Ebook dapat digunakan sebagai bahan ajar alternatif pembelajaran jarak jauh saat pandemi Covid-19. Siswa belajar dari rumah dengan menggunakan ebook yang sangat membantu dalam pembelajaran jarak jauh.

Pemerintah telah menyediakan buku teks pelajaran yang bermutu melalui Buku Sekolah Elektronik (BSE) atau ebook. Tetapi tidak didukung dengan minat baca yang tinggi. Hasil penelitian UNESCO tahun 2016 bahwa minat baca di Indonesia sebesar $0,001 \%$ yang artinya masih rendah. Hal tersebut membuat Indonesia berada pada urutan kedua dari bawah untuk literasi berdasarkan Riset World's Most Literate Nations Ranked yang dilakukan oleh Central Connecticut State Univesity pada Maret 2016, Indonesia menduduki peringkat ke-60 dari 61 negara soal minat membaca (Hasibuan, 2020). Hal tersebut dikarenakan umumnya siswa lebih tertarik dengan teknologi yang sifatnya untuk hiburan seperti games online, media sosial, chatting, menonton video atau film dibandingkan membaca.

Kemajuan teknologi pada era globalisasi menggantikan penggunaan buku teks menjadi buku elektronik atau ebook karena dinilai lebih praktis, dapat digunakan dimana saja, dan kapan saja. Perangkat untuk membuka ebook banyak dimiliki oleh sebagian besar masyarakat pada era globalisasi seperti smartphone, laptop, tablet. Penelitian Fojtik (2015) pada tahun 2004 dan 2014 menyatakan bahwa penggunaan perangkat selular semakin meningkat dari tahun 2004 hingga 2014 contohnya penggunaan notebook, smartphone dan tablet untuk membuka ebook. Hal ini tentunya dapat mendukung dalam penggunaan ebook secara maksimal.

Ketersediaan ebook saat ini cenderung memuat materi pelajaran dan tidak membuat siswa dapat menemukan pengetahuannya sendiri. Seharusnya ebook disesuaikan dengan kebutuhan siswa atau pendidik agar dapat memaksimalkan kegiatan pembelajaran khususnya untuk pembelajaran jarak jauh. Biologi sebagai satu dari sekian banyak mata pelajaran yang dipelajari oleh siswa SMA jurusan IPA dapat dibuat ebook yang sesuai dengan kebutuhan atau materi yang diajarkan. Maka ebook perlu dirancang agar siswa dapat dilatih menemukan sendiri pengetahuannya dengan menggunakan discovery learning.

Ekosistem adalah salah satu kompetensi dasar yang perlu pengamatan langsung agar pembelajaran menjadi bermakna. Model pembelajaran yang cocok untuk materi tersebut adalah discovery learning. Pembelajaran discovery learning menekankan pada keaktifan siswa untuk menemukan konsep dan materinya sendiri melalui kegiatan eksperimen (Aslam \& Auliandari, 2017). Pembelajaran dengan model discovery learning juga membantu siswa dalam menyelesaikan permasalahan sampai dengan mengambil keputusan yang tepat. Anders (2011) menyatakan bahwa discovery learning merupakan model pembelajaran yang membuat siswa melakukan eksplorasi, mencari tahu, dan menemukan sendiri fakta-fakta yang ada selama proses pembelajaran, sehingga siswa dapat berperan aktif untuk membuat, mengintegrasikan, dan menggeneralisasi pengetahuannya. Jew (2012) menyatakan bahwa discovery learning dapat meningkatkan penguasaan materi, retensi, dan transfer pengetahuan sehingga pembelajaran 
lebih bermakna dan membuat siswa dapat berpikir konstruktivisme atau membangun pengetahuannya sendiri melalui fakta dan pengalaman. Model discovery learning juga menekankan pada keaktifan siswa dalam menemukan konsep dan materinya sendiri melalui kegiatan eksperimen-eksperimen (Mubarok \& Sulistyo, 2014)

Format ebook yang digunakan adalah epub (electronic publication) karena spesifikasinya memiliki banyak fitur serta dapat memuat elemen interaktif dan merupakan format terbuka sehingga penerbit atau pembaca tidak perlu membayar biaya royalti (Nakajima et al., 2013). Keunggulan ebook yang dibuat dapat menyesuaikan tampilan teks berdasarkan ukuran perangkat yang digunakan. Aplikasi yang digunakan untuk membuat ebook dengan format epub adalah sigil. Haritz (2013) menyatakan bahwa sigil merupakan sebuah software editor untuk epub yang bersifat open source dan dapat mendukung import file video dan audio.

Berdasarkan kondisi tersebut, maka dikembangkan ebook sebagai salah satu solusi menyiapkan bahan ajar khusus untuk pembelajaran jarak jauh. Ebook yang dikembangkan menggunakan model discovery learning agar pembelajaran menjadi lebih bermakna bagi siswa. Ebook yang dihasilkan berupa format epub yang berisi materi ekosistem untuk kelas X MIPA dan produk diberi nama Ecopub (Ebook Ecosystem Publication).

\section{METODE}

Metode penelitian yang digunakan adalah research and development yang dikembangkan oleh Gall \& Borg (2007). Tahapan penelitian tersebut meliputi pengambilan data awal, perencanaan, pembuatan produk awal, uji coba skala kecil, revisi, dan uji coba skala besar.

Tahapan pertama mencari data awal melalui 30 siswa dan 2 orang guru Biologi di SMAN 48 Jakarta untuk mengetahui bahan ajar yang biasa digunakan di sekolah, ketersediaan bahan ajar di sekolah, dan perangkat seluler yang dimiliki siswa. Data awal tersebut didapatkan dari hasil kuesioner dan wawancara. Tahapan kedua melakukan perencanaan membuat bahan ajar berdasarkan kurikulum dan silabus yang digunakan pada sekolah tersebut. Tahapan ketiga adalah penyusunan ebook dengan menggunakan aplikasi sigil yang divalidasi oleh ahli materi, bahasa, dan media. Tahapan keempat dilakukan uji coba pada kelompok kecil dengan jumlah sepuluh orang siswa diambil secara acak dari siswa kelas $\mathrm{X}$ yang belum mendapatkan materi ekosistem. Tahapan kelima melakukan revisi produk berdasarkan uji coba skala kecil, dan tahapan keenam dengan menguji bahan ajar tersebut terhadap 60 peserta didik kelas X MIPA di SMAN 48 Jakarta dengan teknik purposive sampling.

Analisis data menggunakan skala likert untuk menilai kualitas bahan ajar menurut ahli media, ahli materi dan bahasa. Kategori penilaian dari tim ahli setiap komponen dipersentasekan berdasarkan Tabel 1 menurut Riduwan (2010) berikut ini..

Tabel 1. Kategori Persentase Penilaian

\begin{tabular}{lc}
\hline \multicolumn{1}{c}{ Persentase } & Kategori \\
\hline $81-100 \%$ & Sangat Baik \\
$61-80 \%$ & Baik \\
$41-60 \%$ & Cukup \\
$21-40 \%$ & Kurang \\
$\leq 20 \%$ & Sangat Kurang \\
\hline
\end{tabular}

\section{HASIL DAN PEMBAHASAN}

Hasil penelitian pengembangan pada tahapan pertama dilakukan dengan mengumpulkan data awal dari kuesioner yang diisi oleh 30 siswa, serta wawancara oleh guru mata pelajaran. Hasil pengumpulan data awal tersebut disajikan pada Tabel 2 berikut ini.

Tabel 2. Hasil Kuesioner Siswa

\begin{tabular}{|c|c|c|c|}
\hline No & Indikator & Pernyataan & Persentase \\
\hline \multirow[t]{2}{*}{1} & \begin{tabular}{l}
\multicolumn{2}{l}{ Pembelajaran } \\
biologi di \\
kelas X
\end{tabular} & $\begin{array}{l}\text { Pendapat siswa } \\
\text { tentang } \\
\text { pentingnya } \\
\text { materi } \\
\text { ekosistem }\end{array}$ & $\begin{array}{l}57 \% \text { siswa } \\
\text { menjawab } \\
\text { bahwa materi } \\
\text { ekosistem } \\
\text { penting untuk } \\
\text { dipelajari }\end{array}$ \\
\hline & & $\begin{array}{l}\text { Kesulitan } \\
\text { memahami } \\
\text { materi Biologi }\end{array}$ & $\begin{array}{l}69 \% \text { siswa sulit } \\
\text { memahami } \\
\text { materi } \\
\text { ekosistem }\end{array}$ \\
\hline
\end{tabular}

EDUSAINS, Volume 13 Nomor 02 Tahun 2021, 121-128 This is an open access article under CC-BY-SA licence | p-ISSN 1979-7281 | e-ISSN 2443-1281 


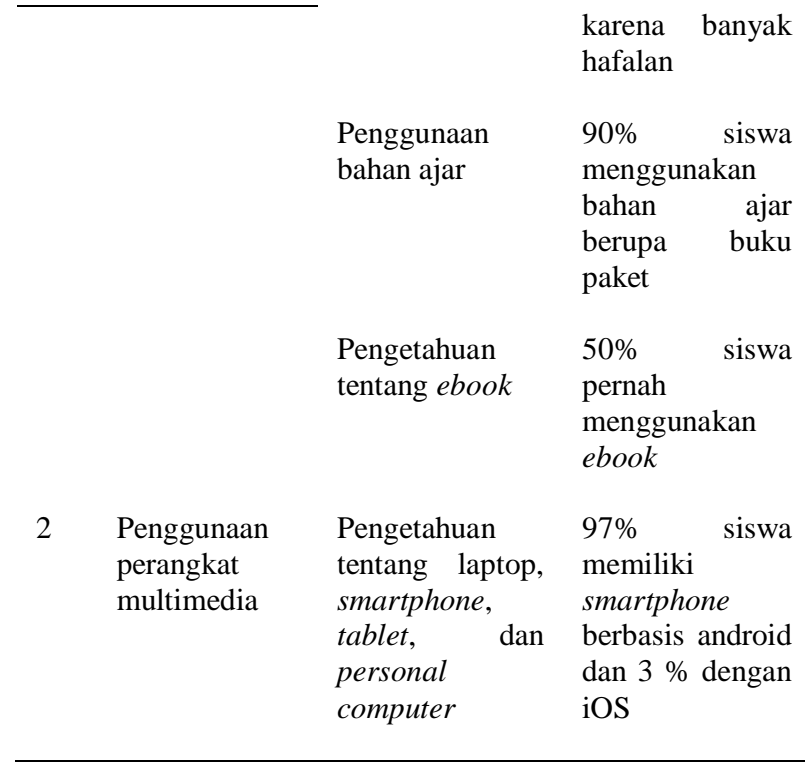

Berdasarkan Tabel 2 diketahui bahwa siswa yang menjawab materi ekosistem penting untuk dipelajari sebanyak $57 \%$. Hal tersebut dikarenakan ekosistem masuk ke dalam materi tuntutan kurikulum 2013 dan materi ekosistem juga membuat siswa lebih mengenal lingkungan sekitar serta mengetahui interaksi antar komponen ekosistem di dalamnya. Siswa yang mengalami kesulitan dalam memahami materi ekosistem sebanyak $69 \%$ dikarenakan menurut siswa banyak terdapat istilah dalam materi tersebut yang sulit untuk dimengerti. Siswa yang menggunakan buku paket sebagai sumber bahan ajar yang utama dengan persentase sebesar $90 \%$ dikarenakan buku cetak mudah dicari, tersedia, dan ada yang dipinjamkan dari perpustakaan sekolah. Siswa yang menggunakan ebook sebesar 50\% dengan cara mengunduh dari internet. Siswa memiliki smartphone dengan sistem android sebanyak $97 \%$ dan 3\% dengan sistem iOS. Smartphone atau laptop yang dimiliki siswa dapat membantu dalam mengoperasikan ebook. Menurut Ali \& Asrori (2014) bahwa ebook lebih efektif dan efisien dalam mengoperasikannya karena hanya dibutuhkan personal computer seperti smartphone, laptop, tablet.

Tahapan kedua dilakukan perencanaan yang menghasilkan draft materi ekosistem dengan model discovery learning. Draft berisi sampul depan, daftar isi, kompetensi dasar, indikator pencapaian kompetensi, tujuan pembelajaran, peta konsep, pendahuluan, konsep materi ekosistem, komponen ekosistem, energi dalam ekosistem, suksesi, kegiatan pembelajaran praktikum, ringkasan, latihan soal, glosarium, dan daftar pustaka. Sampul depan dibuat dengan semenarik mungkin untuk menarik minat siswa dalam mambaca. Bagian pendahuluan berisi stimulus untuk merangsang siswa melakukan penalaran terhadap suatu peristiwa. Sub materi pada energi dalam ekosistem disajikan gambar rantai makanan, jaring makanan, piramida biomasa, piramida jumlah, dan piramida energi. Bagian kegiatan pembelajaran praktikum dibuat dengan memperhatikan sintaks discovery learning. Bagian latihan soal terdiri dari soal-soal yang membuat siswa berpikir secara logis.

Tahap ketiga menghasilkan ebook yang dibuat menggunakan aplikasi sigil dan dioperasikan melalui smartphone, laptop, atau personal computer lainnya. Ebook model discovery learning berupa format epub (electronic publication) yang dapat dioperasikan dengan mengunduh aplikasi sesuai perangkat yang digunakan seperti supreader dan icecream ebook reader. Tampilan ebook ketika dioperasikan terlihat lebih menarik, hyperlink dan tombol navigasi dapat membantu perpindahan dengan cepat ke bagian yang diinginkan, pencarian kata kunci juga mudah dilakukan. Tabel 3 menyajikan story board atau tampilan yang terihat pada ebook ketika digunakan.

Tabel 3. Story Board Ebook

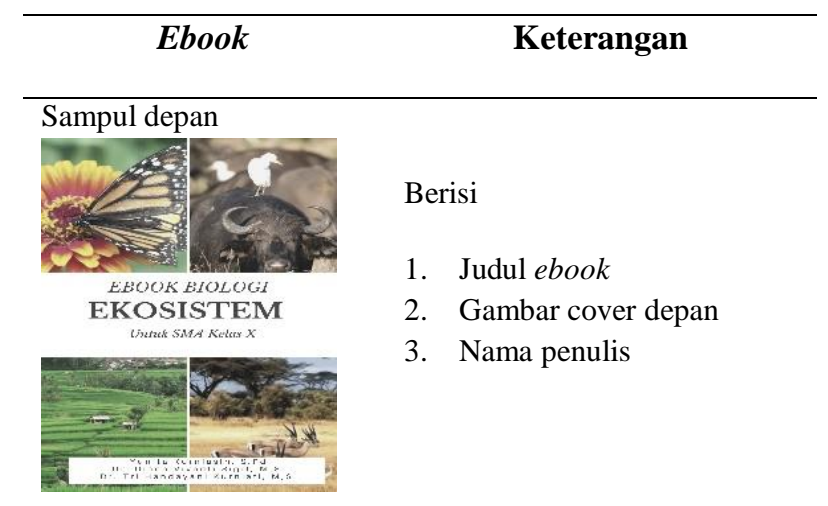


Daftar isi

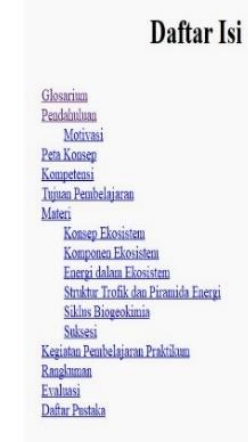

Daftar isi berisi :

1. Dilengkapi dengan panduan untuk pengguna, KD dan indikator pelajaran serta peta konsep

2. Berisi materi pelajaran yang diawali dengan stimulus

3. Terdapat kegiatan pembelajaran menggunakan discovery learning dengan tahapan stimulus, merumuskan masalah, pembuktian, kesimpulan, evaluasi

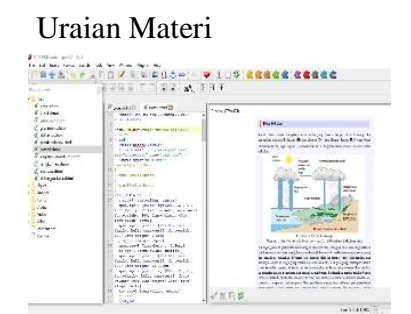

Contoh uraian materi dilengkapi dengan gambar dan video

Contoh tampilan latihan soal dengan menggunakan aplikasi gitden reader dari handphone android

Tabel 3 menunjukkan hasil visualisasi dari ebook ketika digunakan. Sampul depan tercantum nama-nama penulis serta peruntukkan ebook tersebut. Tampilan daftar isi yang dapat dipilih untuk menuju ke menu yang diinginkan. Pada menu daftar isi terdapat kegiatan praktikum yang memuat langkah discovery learning seperti stimulus, merumuskan masalah, pembuktian, kesimpulan, dan evaluasi. Uraian materi ditampilkan dalam bentuk teks, gambar, dan video. Latihan soal berisi soal-soal hots.

Ebook selanjutnya dilakukan validasi oleh ahli media, ahli materi dan ahli bahasa. Hasil validasi ahli media disajikan pada Tabel 4 berikut ini.

Tabel 4. Hasil Validasi Ahli Media

\begin{tabular}{clcc}
\hline No & \multicolumn{1}{c}{ Aspek } & $\begin{array}{c}\text { Persentase } \\
(\%)\end{array}$ & Kategori \\
\hline 1 & $\begin{array}{l}\text { Kelengkapan } \\
\text { penyajian }\end{array}$ & 95 & $\begin{array}{c}\text { Sangat } \\
\text { baik }\end{array}$ \\
2 & $\begin{array}{l}\text { Desain tampilan } \\
\text { Pengunaan huruf }\end{array}$ & 80 & $\begin{array}{c}\text { Baik } \\
\text { Sangat } \\
\text { baik } \\
\text { Cukup }\end{array}$ \\
4 & $\begin{array}{l}\text { Gambar, } \\
\text { animasi, video }\end{array}$ & 65 & Baik \\
5 & Tombol navigasi & 80 & $\begin{array}{c}\text { Sangat } \\
\text { baik }\end{array}$ \\
\hline & Total Rata-rata & 84 & \\
\hline
\end{tabular}

Tabel 4 menunjukkan validasi ahli media dengan persentase rata-rata sebesar $84 \%$ yang artinya valid dan sangat baik untuk digunakan berdasarkan kriteria Riduwan (2010). Persentase hasil validasi ahli media dari aspe $\quad \mathrm{pk}$

kelengkapan penyajian, desain tampilan, penggunaan huruf, gambar, animasi, video, dan tombol animasi yang digunakan sesuai dengan format Badan Standar Nasional Pendidikan (2006). Hal ini ditandai dari font yang digunakan adalah times new roman, ukuran 12, spasi 1 . Tombol navigasi mudah digunakan karena dengan mengklik navigasi daftar isi maka akan tampil judul-judul sub bab yang ingin di buka, dan jika sudah tampil halaman yang diinginkan maka pada akhir dari setiap sub bab terdapat tombol navigasi untuk menuju ke daftar isi, pendahuluan, atau rangkuman.

Validator memberikan saran dan masukkan yaitu dibutuhkan fitur video yang menunjang materi pembelajaran agar ciri khas ebook lebih tampak jika dibandingkan pdf. Validator juga menyarankan agar masing-masing sub bagian materi dibuat di halaman terpisah, sehingga jika pada daftar isi diklik motivasi, maka yang tampil hanya halaman motivasi, tanpa menyambung ke peta konsep dan bagian-bagian lainnya. Resolusi gambar dibuat lebih tinggi agar gambar lebih jelas.

Ebook divalidasi oleh dua orang ahli materi dan bahasa. Penilaian validasi tersebut dilihat dari aspek kelayakan isi, penyajian, dan bahasa. Masing-masing dari aspek tersebut dikategorikan berdasarkan besaran persentasenya. Ahli materi dan bahasa dilakukan oleh seorang dosen di salah satu universitas swasta di Jakarta. Validator kedua 
merupakan seorang penulis buku biologi terbitan erlangga. Buku hasil karangnya tersebut digunakan oleh banyak siswa dan dijual secara luas. Tabel 5 menyajikan hasil validasi dari ahli materi dan bahasa.

Tabel 5. Validasi Ahli Materi dan Bahasa

\begin{tabular}{|c|c|c|c|c|c|}
\hline \multirow{2}{*}{ No } & \multirow{2}{*}{ Aspek } & \multicolumn{2}{|c|}{$\begin{array}{c}\text { Persentase } \\
(\%)\end{array}$} & \multirow[t]{2}{*}{$\begin{array}{l}\text { Rata- } \\
\text { rata }\end{array}$} & \multirow[t]{2}{*}{$\begin{array}{c}\text { Kateg } \\
\text { ori }\end{array}$} \\
\hline & & $\begin{array}{c}\text { Ahli } \\
1\end{array}$ & $\begin{array}{c}\text { Ahli } \\
2\end{array}$ & & \\
\hline \multirow[t]{2}{*}{1} & $\begin{array}{l}\text { Kelayakan isi } \\
\text { a. Dimensi } \\
\text { pengetahuan }\end{array}$ & 90 & 90 & 90 & $\begin{array}{c}\text { Sangat } \\
\text { baik }\end{array}$ \\
\hline & $\begin{array}{l}\text { b. Dimensi } \\
\text { ketrampilan }\end{array}$ & 88 & 80 & 84 & $\begin{array}{c}\text { Sangat } \\
\text { baik }\end{array}$ \\
\hline \multirow[t]{4}{*}{2} & $\begin{array}{l}\text { Penyajian } \\
\text { a. Teknik } \\
\text { penyajian }\end{array}$ & 96 & 100 & 98 & $\begin{array}{c}\text { Sangat } \\
\text { baik }\end{array}$ \\
\hline & $\begin{array}{l}\text { b. Pendukung } \\
\text { penyajian } \\
\text { materi }\end{array}$ & 88 & 84 & 86 & $\begin{array}{c}\text { Sangat } \\
\text { baik }\end{array}$ \\
\hline & $\begin{array}{l}\text { c. Penyajian } \\
\text { pembelajaran }\end{array}$ & 88 & 80 & 84 & $\begin{array}{c}\text { Sangat } \\
\text { baik }\end{array}$ \\
\hline & $\begin{array}{l}\text { d. Kelengkapan } \\
\text { penyajian }\end{array}$ & 100 & 100 & 100 & $\begin{array}{c}\text { Sangat } \\
\text { baik }\end{array}$ \\
\hline \multirow[t]{2}{*}{3} & Bahasa & 93 & 73 & 83 & $\begin{array}{c}\text { Sangat } \\
\text { baik }\end{array}$ \\
\hline & $\begin{array}{l}\text { Total Rata- } \\
\text { rata }\end{array}$ & & & 89,3 & $\begin{array}{c}\text { Sangat } \\
\text { baik }\end{array}$ \\
\hline
\end{tabular}

Tabel 5 menunjukkan hasil validasi ahli materi dan bahasa rata-rata sebesar $89,3 \%$ yang artinya memiliki kategori sangat baik berdasarkan Riduwan (2010). Kelayakan isi yang memuat dimensi pengetahuan sebesar $90 \%$ dan dimensi keterampilan sebesar $84 \%$ ditunjukkan dari adanya pemaparan materi pada ebook dan kegiatan keterampilan seperti kegiatan praktikum ekosistem menggunakan discovery learning. Aspek penyajian rata-rata $92 \%$ dengan disajikan pendahuluan (studi kasus), gambar, serta kelengkapan materi yang diberikan.

Masukkan dan saran dari validator yaitu memperbaiki ejaan dan penulisan materi karena ditemukan ada kata-kata yang ejaannya tidak tepat. Penulisan kata dan kalimat harus sesuai dengan KBBI. Penulisan kalimat tertentu diperlukan perbaikan pada susunan kalimatnya agar lebih mudah dipahami. Penulisan huruf besar yang tidak tepat sehingga harus diperbaiki.

Kualitas ebook memiliki rata-rata persentase sangat baik menurut Riduwan (2010).
Hal ini dikarenakan cakupan materi lengkap dengan menyajikan isi sesuai pengembangan kompetensi dasar serta tujuan pembelajaran yang ingin dicapai. Fitur pendahuluan pada ebook terdapat motivasi agar siswa tertarik untuk membaca ebook. Terdapat peta konsep, kompetensi dan tujuan pembelajaran. Fitur materi pada ebook terdiri atas uraian materi yang disisipkan gambar dan video. Fitur langkah kegiatan praktikum yang terdapat pada ebook menuntun siswa untuk melakukan pembelajaran discovery learning. Fitur lainnya di lengkapi dengan rangkuman dan evaluasi. Menurut Badan Standar Nasional Pendidikan (2006) isi ebook tersebut sudah sesuai dengan instrumen penilaian buku teks pelajaran Biologi SMA/MA.

Berdasarkan masukkan dan saran dari ahli media, ahli materi dan bahasa dilakukan perbaikan terhadap ebook yang telah dibuat. Perbaikan ebook tersebut disajikkan pada Tabel 6 berikut ini.

Tabel 6. Perbaikan Ebook

\begin{tabular}{ll}
\hline \multicolumn{1}{c}{ Sebelum } & \multicolumn{1}{c}{ Sesudah } \\
\hline $\begin{array}{l}\text { Ebook belum dilengkapi } \\
\text { video pembelajaran } \\
\text { yang menunjang materi }\end{array}$ & $\begin{array}{l}\text { Ebook ditambahkan video tentang } \\
\text { siklus karbon, hidrologi, dan } \\
\text { fosfor yang membantu siswa } \\
\text { memahami materi }\end{array}$ \\
$\begin{array}{l}\text { Terdapat kalimat atau } \\
\text { kata yang ejaannya tidak } \\
\text { tepat }\end{array}$ & $\begin{array}{l}\text { Menggunakan KBBI dan Kateglo } \\
\text { dalam penyusunan materi } \\
\text { ekosistem }\end{array}$ \\
$\begin{array}{l}\text { Terdapat gambar yang } \\
\text { resolusinya rendah }\end{array}$ & $\begin{array}{l}\text { Gambar diganti dengan resolusi } \\
\text { yang lebih tinggi sehingga lebih } \\
\text { jelas }\end{array}$ \\
&
\end{tabular}

Tahapan keempat dilakukan uji skala kecil dengan jumlah 10 orang siswa. Hasil rata-rata uji skala kecil sebesar $80 \%$ yang artinya respon siswa terhadap ebook baik menurut Riduwan (2010). Tabel 7 menunjukkan uji coba skala kecil.

Tabel 7. Hasil Kuesioner Uji Coba Skala Kecil

\begin{tabular}{|c|c|c|c|}
\hline No & $\begin{array}{c}\text { Komponen } \\
\text { Penilaian }\end{array}$ & $\begin{array}{c}\text { Persentase } \\
(\%)\end{array}$ & Kategori \\
\hline 1 & $\begin{array}{ll}\text { Kejelasan } & \text { informasi } \\
\text { pada } \text { ebook }\end{array}$ & 83 & $\begin{array}{c}\text { Sangat } \\
\text { baik }\end{array}$ \\
\hline 2 & Penggunaan bahasa & 84 & $\begin{array}{l}\text { Sangat } \\
\text { Baik }\end{array}$ \\
\hline 3 & Desain tampilan & 71 & Baik \\
\hline 4 & Penggunaan huruf & 86 & $\begin{array}{c}\text { Sangat } \\
\text { baik }\end{array}$ \\
\hline
\end{tabular}




\begin{tabular}{llcc}
5 & $\begin{array}{l}\text { Gambar, animasi, } \\
\text { video }\end{array}$ & 79 & Baik \\
6 & Tombol navigasi & 76 & Baik \\
7 & $\begin{array}{l}\text { Ebook sebagai sumber } \\
\text { materi ekosistem }\end{array}$ & 80 & Baik \\
\hline Rata-Rata & 80 & Baik \\
\hline
\end{tabular}

Tabel 7 menyatakan bahwa informasi yang diberikan dapat dibaca dan dipahami walaupun masih ada beberapa kata yang masih asing atau kurang dimengerti. Respon siswa terhadap penggunaan bahasa sangat baik karena menggunakan bahasa sesuai EYD dan mudah dipahami. Desain tampilan menurut siswa sangat baik karena warna yang digunakan sesuai dengan kebutuhan. Respon terhadap penggunaan huruf sangat baik karena huruf jelas dan mudah dibaca. Respon terhadap tampilan baik karena terdapat gambar yang jelas. Respon terhadap tampilan video sebesar baik karena video pembelajaran manampilakn materi yang abstrak, namun ada kekurangannya yaitu saat menggunakan personal computer seperti laptop, video tidak bisa diputar dan hanya bisa diputar jika menggunakan handphone. Surasmi (2016) menyatakan bahwa adanya video dapat membantu siswa dalam mengamati suatu peristiwa penting yang sulit dijelaskan dengan kalimat atau kata-kata.

Tombol navigasi baik dikarenakan letak navigasi baik namun tampilannya kurang menarik. Ebook sebagai sumber materi ekosistem baik dengan respon siswa bahwa penggunakan ebook lebih bagus dibanding dengan menggunakan power point karena dengan adanya ebook dapat langsung menampilkan video untuk diputar. Berdasarkan hasil kuesioner penilaian yang diisi oleh siswa maka Ebook yang dikembangkan dapat dijadikan sebagai bahan ajar yang sesuai dengan kebutuhan siswa serta sesuai dengan standar penilaian dari Badan Standar Nasional Pendidikan.

Hasil uji coba ebook pada skala besar dengan memberikan kuesioner kepada 60 siswa menghasilkan persentase rata-rata persentase sebesar $87 \%$ dengan kategori sangat baik menurut Riduwan (2010). Tabel 8 menyajikkan hasil kuesioner uji coba pada skala besar.

Tabel 8. Hasil Kuesioner Uji Coba Skala Besar

\begin{tabular}{|c|c|c|c|}
\hline No & $\begin{array}{c}\text { Komponen } \\
\text { Penilaian }\end{array}$ & $\begin{array}{c}\text { Persentase } \\
(\%)\end{array}$ & Kategori \\
\hline 1 & $\begin{array}{l}\text { Kejelasan } \\
\text { informasi pada } \\
\text { ebook }\end{array}$ & 85 & Sangat baik \\
\hline 2 & Penggunaan bahasa & 85 & Sangat baik \\
\hline 3 & Desain tampilan & 85 & Sangat baik \\
\hline 4 & Penggunaan huruf & 87 & Sangat baik \\
\hline 5 & $\begin{array}{l}\text { Gambar, animasi, } \\
\text { video }\end{array}$ & 87 & Sangat baik \\
\hline 6 & Tombol navigasi & 90 & Sangat baik \\
\hline \multirow[t]{2}{*}{7} & $\begin{array}{lr}\text { Ebook } & \text { sebagai } \\
\text { sumber } & \text { materi } \\
\text { ekosistem } & \end{array}$ & 90 & Sangat baik \\
\hline & Rata-Rata & 87 & Sangat baik \\
\hline
\end{tabular}

Hasil uji coba skala besar pada Tabel 8 memiliki kategori sangat baik karena ejaan atau penulisan sesuai dengan KBBI sehingga lebih mudah dipahami. Ebook dilengkapi dengan gambar dan video tentang daur biogeokimia yang menunjang materi pembelajaran sehingga membuat siswa lebih paham dengan materi yang disajikan. Menurut Munir (2013) gambar dapat menjelaskan suatu informasi dengan lebih bermakna. Widyanita, Budiono, \& Pratiwi (2012) menyatakan bahwa ebook dapat dikombinasikan dengan suara, grafik, gambar, animasi, dan video sehingga informasi yang diberikan lebih bervariasi.

Pada uji coba skala besar, siswa diberikan pretest dan postest untuk mengetahui pemahaman tentang materi ekosistem. Hasilnya disajikan pada Tabel 9 berikut ini.

Tabel 9. Pretest-Postest Pemahaman Materi Ekosistem Siswa

\begin{tabular}{lccc}
\hline & Minimum & Maksimum & $\begin{array}{c}\text { Rata- } \\
\text { Rata }\end{array}$ \\
\hline Pretest & 57 & 85 & 71,75 \\
Postest & 65 & 93 & 80,03 \\
\hline
\end{tabular}

Pemahaman siswa mengenai materi ekosistem dengan menggunakan ebook mengalami peningkatan antara sebelum dan setelah menggunakan ebook yang ditandai dengan peningkatan rata-rata skor dari pretest ke postest. Hasil ini menunjukkan bahan ajar yang berbasis digital seperti ebook sesuai digunakan untuk pembelajaran daring atau jarak jauh. Hasil penelitian dari Fathoni (2021) menyatakan bahwa buku digital merupakan alternatif dan solusi yang 
tepat untuk pembelajaran jarak jauh dan mendukung program pelaksanaan merdeka belajar.

Ebook ini dibuat dengan tujuan untuk membantu siswa dalam belajar secara mandiri selama pembelajaran jarak jauh. Ebook juga dirancang agar siswa mampu menemukan pengetahuannya sendiri melalui langkah-langkah model pembelajaran discovery learning yang disajikan pada menu kegiatan praktikum. Siswa melakukan praktikum pengamatan ekosistem di sekitar lingkungan rumah diawali dengan stimulus, membuat hipotesis, melakukan percobaan, mengolah hasil, dan evaluasi. Bentuk tagihan dari kegiatan tersebut berupa laporan praktikum serta video siswa ketika sedang melakukan pengamatan sesuai petunjuk yang diberikan.

Ebook model discovery learning membuat siswa mampu membangun pengalamannya sendiri dengan dibantu melalui fitur-fitur yang ada di dalamnya. Salah satunya fiturnya adalah kegiatan pengamatan praktikum ekosistem yang menggunakan langkah-langkah discovery learning seperti memberikan stimulus, merumuskan masalah atau hipotesis, melakukan kegiatan praktikum, membuat kesimpulan, dan melakukan evaluasi. Kurniati et al (2016) menyatakan bahwa discovery learning merupakan pembelajaran aktif yang membuat siswa dapat membangun pengetahuannya sendiri. Pengembangan ini didukung hasil penelitian Aslam \& Auliandari (2017) menyatakan bahwa model pembelajaran discovery learning sesuai untuk digunakan dalam materi ekologi submateri komponen ekosistem beserta hubungan antar komponen ekosistem yang membutuhkan pengamatan langsung ke lingkungan.

Berdasarkan hasil uji coba terbukti bahwa ebook model discovery learning dapat membantu siswa dalam memahami materi ekosistem. Discovery learning menekankan siswa dapat mandiri dan berpikir kritis dalam mencari informasi pembelajarannya (Dina, Mawarsih, \& Suprapto, 2015). Selain itu, discovery learning menjadikan siswa peka terhadap lingkungan dalam mencari, mengidentifikasi dan mengelola solusi dari suatu permasalahan (Cahyani, Rizki, Astuti, \& Mariadi, 2015). Sehingga ebook ini cocok digunakan saat pandemi Covid-19 yang proses pembelajaran secara daring dengan memanfaatkan smartphone atau laptop dimana ebook merupakan alternatif dan solusi untuk mempermudah pembelajaran daring. Bahan ajar yang berbasis digital seperti ebook sesuai digunakan untuk pembelajaran daring atau jarak jauh. Hasil penelitian dari Fathoni (2021) menyatakan bahwa buku digital merupakan alternatif dan solusi yang tepat untuk pembelajaran jarak jauh dan mendukung program pelaksanaan merdeka belajar. Shiratuddin, Landoni, Gibb, \& Hassan (2003) tentang teknologi ebook dan manfaatnya dalam dunia pendidikan yaitu penggunaan ebook dapat meningkatkan interaksi antara pendidik dan siswa, serta menjadikan siswa lebih tertarik menggunakan ebook selama kegiatan pembelajaran jarak jauh.

\section{PENUTUP}

Penelitian ini menghasilkan produk berupa ebook model discovery learning dengan format epub materi ekosistem. Produk dikembangkan melalui enam tahapan yaitu analisis kebutuhan, perencanaan, pengembangan produk, uji coba skala kecil, revisi, dan uji coba skala besar. Hasil validasi tiga orang ahli dari segi materi dan bahasa, serta media didapatkan bahwa produk memiliki kualitas produk dengan kategori sangat baik dan layak digunakan. Keunggulan dari ebook ini adalah memuat langkah-langkah pembelajaran discovery learning seperti stimulus, hipotesis, melakukan percobaan, hasil, dan evaluasi. Tingkat pemahaman siswa tentang ekosistem juga mengalami peningkatan setelah menggunakan ebook. Serta hasil respon siswa terhadap ebook model discovery learning materi ekosistem juga memiliki kategori sangat baik.

Saran untuk penelitian ini yaitu ebook dapat disebarluaskan dengan skala yang lebih besar agar mendapatkan saran dan masukkan yang lebih banyak sehingga produk yang dihasilkan semakin baik. Ebook juga dapat didaftarkan hak ciptanya sabagai kekayaan intelektual untuk melindungi 
hak eksklusif, hak moral, dan ekonomi bagi pembuatnya.

\section{UCAPAN TERIMA KASIH}

Terima kasih penulis ucapkan kepada semua pihak yang telah membantu dalam proses penelitian pengembangan ini. Terutama kepada dosen Universitas Negeri Jakarta, guru dan siswa SMAN 48 Jakarta yang telah mendukung penelitian ini.

\section{DAFTAR PUSTAKA}

Ali, M., \& Asrori, M. (2014). Metodologi dan Aplikasi Riset Pendidikan. Jakarta: Bumi Aksara.

Anders, B. A. (2012). Human Motivations and Discovery Learning. IGI Global. doi: 10.4018/978-1-61350-320-1.

Aslam, D., \& Auliandari, L. (2017). Pengaruh Model Pembelajaran Discovery Learning Terhadap Hasil Belajar Siswa Materi Ekologi Berbantu Data Penelitian Iklim Mikro Ruang Terbuka Hijau Berdasarkan Habitus Vegetasi. Prosiding Seminar Nasional Pendidikan, 2(1).

Asyhari, A., \& Silvia, H. (2016). Pengembangan Media Pembelajaran Berupa Buletin dalam Bentuk Buku Saku untuk Pembelajaran IPA Terpadu. Jurnal Ilmiah Pendidikan Fisika AlBiRuNi, 05(1), 1-13. doi:10.24042/jpifalbiruni.v5i1.100

Badan Standar Nasional Pendidikan. (2006). Instrumen Penilaian Tahap II Buku Teks Pelajaran Biologi SMA/MA. Jakarta: Badan Standar Nasional Pendidikan.

Belawati, T. (2003). Pengembangan Bahan Ajar. Jakarta: Universitas Terbuka.

Cahyani, T., Rizki, M., Astuti, D., \& Mariadi. (2015). Pengaruh Pembelajaran Discovery Learning terhadap Kemampuan Berpikir Logis Siswa Kelas X MIA Muhammadiyah 1 Surakarta Tahun Pelajaran 2013/2014. Jurnal Pendidikan Biologi, 7(1).

Dina, A., Mawarsih, D. V., \& Suprapto, R. (2015). Implementasi Kurikulum 2013 pada Perangkat Pembelajaran Model Discovery Learning Pendekatan
Scientific terhadap Kemampuan Matematis Materi Geometri SMK. Jurnal JKPM, 2(1).

Fathoni, B. (2021). Buku Digital Sejarah Sebagai Alternatif dan Solusi Mengajarkan Nilai-Nilai Kepahlawanan dalam Pelaksanaan Merdeka Belajar. Prosiding Seminar Nasional Pendidikan Fakultas Keguruan dan Ilmu Pendidikan Universitas Lampung, 185194.

Fojtik, R. (2015). E-books and Mobile Device in Education. Procedia Journal Social and Behavioral Sciences, 182, 742 $745 . \quad$ Retrieved from www.sciencedirect.com

Gall, M., Gall, J. P., \& Borg, W. R. (2007). Educational Research : An Introduction Fifth Edition. New York: Longman.

Haritz, C. N. (2013). Pembuatan Buku Digital Tutorial Pembuatan Buku Digital Interaktif Menggunakan Sigil. Seamolec.

Hasibuan, F. M. (2020). Indonesian Students Literacy Condition and How to Improve It. Researchgate.

Jew, S. H. (2012). Who Are Self-Discovery Learners Online? A Literature Review. USA: Constructing Self-Discovery Learning Space Online.

Kurniati, I. W., Pujiastuti, E., \& Kurniasih, A. W. (2016). Model Pembelajaran Discovery Learning Berbantuan Smart Sticker untuk Meningkatkan Disposisi Matematika dan Kemampuan Berpikir Kritis. Kreano Jurnal Matematika Kreatif Inovatif, 8(2), 109-118. doi:http://dx.doi.org/10.15294/kreano.v $8 \mathrm{i} 2.5060$

Mubarok, C., \& Sulistyo, E. (2014). Penerapan Model Pembelajaran Discovery Learning terhadap Hasil Belajar Siswa Kelas X TAV pada Standar Kompetensi Instalasi Sound System di SMK Negeri 2 Surabaya. Jurnal Pendidikan Teknik Elektro, $3(1)$.

Munir. (2013). Multimedia dan Konsep Aplikasi Dalam Pendidikan. Bandung: Penerbit Alfabeta. 
Nakajima, T., Shinoharab, S., \& Tamur, Y. (2013). Typical Functions of eTextbook, Implementation, and Compatibility Verification with use of ePub3 Materials. Procedia Computer Science, 22, 1344-1353. doi:10.1016/j.procs.2013.09.223

Riduwan. (2010). Dasar-Dasar Statistik. Bandung: Alfabeta.

Ruddamayanti. (2013). Pemanfaatan Buku Digital dalam Meningkatkan Minat Baca. Prosiding Seminar Nasional Pendidikan Program Pascasarjana Universitas PGRI Palembang.
Shiratuddin, N., Landoni, M., Gibb, F., \& Hassan, S. (2003). E-book Technology and Its Potential Application in Distance Education. Journal of Digital Information, 3(4).

Surasmi, W. A. (2016). Pemanfaatan Multimedia untuk Mendukung Kualitas Pembelajaran. Prosiding Temu Ilmiah Nasional Guru (TING) VIII, 593-607.

Widyanita, A,. Budiono, D,. \& Pratiwi, R, (2012). Pengembangan Media E-Book Interaktif Pada Materi Struktur dan Fungsi Jaringan Organ Tumbuhan. BioEdu, 1(3). 